\title{
EVALUATION OF JOINT VENTURES IN PROPERTY DEVELOPMENT IN LAGOS, NIGERIA
}

\author{
Oyedeji, Joseph Oyewale* \\ ${ }^{1}$ Department of Estate Management,The Bells University of Technology, Ota, Ogun State, Nigeria \\ E-mail: diranjosh@gmail.com
}

\begin{abstract}
Joint venture is a new financing model adopted in property development. However, there is little or no research in evaluating the model which this study aimed at achieving. The study populations are the members of Real Estate Developers Association of Nigeria in Lagos. Data were gathered through structured questionnaires administered to the study population. Gathered data were presented and analyzed through tables, chats and likert scales. Findings from the study revealed that residential property is the class of property mostly developed through joint venture in the study area. Also, the most prevalent parties that go into a joint venture agreement in the study area are; private property developer and financial institutions and the least prevalent are private property developers and the government. Financing is the most important term in a joint venture agreement in the study area and the least important term is acquisition of equipment. Finally, financing is the most prevalent problem of joint venture in the study area and breach of joint venture agreement is the least. Recommendations were made on how to solve joint ventures problems in property development. Also, there is need for further research on the nature of relationship between parties going into joint ventures.
\end{abstract}

Keywords : Property development, Joint Venture, Property Developers, Lagos, Nigeria

\section{INTRODUCTION}

Property development is a capital intensive investment that requires huge financial commitment. The required financial commitment is usually characterized with difficulties that necessitate the need for innovative sources of real estate finance. Costello and Preller (2010) posited that property development is an integrated process centered on numerous components that link different stages in the development cycle. The scholars buttressed that these interrelated phases requires huge financial commitment. Altona (2008) established that paucity of fund is one of the major problems of property development. The scholar buttressed this assertion by establishing that all the stages of property development require finance, which makes finance to be at the center point of property development.

The need for adequate and good financing method, necessitate the need for innovative means of financing property development. There are different innovative properties financing methods among which are Joint ventures. Joint ventures have been adopted as a financing model in different fields of human endeavors and property development is not left out. Kogut (1988) defined joint venture as an arrangement when two or more parties pool a portion of their resources within a common legal organization for a desired objective. Joint venture is a financial model adopted to finance different projects in different aspects of human endeavor.

Joint venture has been an innovative financial model for property development. There are different models of joint ventures that had been applied to property development, the broad classification of which are public and private sectors driven. However, Salmon (2015) identified the following as consideration for structuring joint ventures; differing tax treatment for possible legal structure, nature of property to be developed and the degree of technical complexity involved in property development.

In addition, joint ventures model in real estate development can be either of the following: private-public partnership, private - private partnership, private developers and governmental agency, private developer and financial institution, private developers and land owners, private developers and individuals. The structure of these different joint ventures structures are characterized with different problems which necessitate the need for examination of the different problems and the existing joint ventures models in the study area. The aim of this 
study is to evaluate joint ventures in property development in Lagos, Nigeria with the view of improving property development in the study area. The objectives of the study are the following: to assess the classes of properties developed through joint ventures in the study area, to examine the nature of the parties going into joint ventures for property development in the study area, to assess the terms of a joint venture agreement and to examine problems associated with joint ventures in the study area.

\section{LITERATURE REVIEW}

\subsection{Joint Venture}

Channon and Sammut-Bonnici (2014) described joint venture as a cooperative strategy where companies can create an alliance in order to combine their resources and capabilities. The primary aim of which is to be positioned for stronger competition. Firms employ joint ventures as a means to reduce the negative effect of competitors by building higher barriers to entry through combining financial resources, research and development, production and distribution channels. Joint venture increases the profitability of an industry by reducing competition in market where the firms are present. Joint venture can be described as a special purpose vehicle that allowed firms to come together to form a formidable force that provides comparative advantage in an industry.

Different reasons have been identified as the motivating factor for the adoption of joint ventures as a business model. Grades (2008) identified joint venture as a model for penetration and expansion of a local market by an international business enterprise. The study posited further that most international businesses go into joint venture with local businesses in order to penetrate and expand their businesses in the new local market. Also, it is a public policy in some countries that a foreign business coming into the country should go into joint venture or other similar business models in order to operate in the country.

Ahmed and Ahmed (2013) described joint venture as a strategy for competitive advantage and for sustainability of business. The study emphasized that in order to benefit from the comparative advantage posture of joint venture, strategic management and good analysis must be done through SWOT analysis of the various firms participating in the joint venture arrangement. The study established that the future of joint venture depends on strategic management. The study identified the following as advantages of joint venture: having access to market information and resources, technological advantage, ability to obtain external capital and special managerial and entrepreneurial capabilities and skills by joint venture members.

In addition to the advantages of joint venture, there are some demerits of joint venture as a business model. Bilas, Cenan and Podrug (2007) posited that the problems of joint venture rely on the form of the joint venture which could be local or international. The scholars posited further that the control which parent company have over the joint venture arrangement determines the nature of the problem. Control of the parent company could be any of the following: majority, same as partner, and minority. The study identified the following as the problems of joint venture: ownership structure, technology transfer, marketing issue, staffing, complementarities of partner's resources contribution, assess to regulatory permit, and trust between management teams.

\subsection{Joint Ventures Agreement}

Joint venture agreement is project specific (Miller, 2004). However, the scholar identified the common provisions of a joint venture agreement peculiar to construction as follows: The date which the joint venture agreement is endorsed, The names, addresses and identification of form of business of parties involved in the joint venture, The joint venture business name, A full description of the joint venture business, A statement that the parties are executing the project under joint venture, The raising of fund by the joint venture parties to finance the work, together with the share to be contributed by each parties, A clause contribution of additional capital and proportion of contribution, statement for sharing of profits and losses which might be in proportion of capital contribution or otherwise, Payment of any fee to the controlling joint venture or sponsor should be clearly stated, If equipment is involved, a specific clause should be included, especially where the parties contribute equipment in different proportion, Signature of parties of all documents relating to contract, bank loans, and indemnity agreement, Appointment of one of the joint ventures parties as general manager or chief executive officer should be included clearly defining not only managerial duties but all other duties of the parties and the procedure to be followed in dealing with unexpected situations, Items to be included in a separate set of financial books kept by 
an independent certified accountant, Provisions to handle the cases of incapacity, death, bankruptcy, or insolvency of a member should be included in the joint venture agreement, The purchase of equipment and materials by the joint venture and the disposal of such equipment and material, which might be through sale with the proceeds treated as ordinary income, or by distributing them to the parties, The acquisition of licenses in the name of joint venture or each of the parties involved as the case may be, Liabilities of the joint venture parties should be well stated, Cost items to the joint venture for the purpose of determining profit or loss, and those items which are not reimbursable to parties of the joint venture should be detailed, When the joint venture will be terminated, how it will be handled, and how such items as guarantees, defects, and insurance will be handled should be stated, The condition under which provisions of the joint venture agreement will be interpreted should be designated.

All these stated provisions of joint venture agreement vary from one joint venture project to another. However, these are the general provision of construction related joint venture agreement.

\subsection{Property Development}

Cloete (1998) defined property development as the process of increasing the value of an existing property (underdeveloped or developed) by the application of material, human and capital resources. Property development involves inputs of different stakeholders and combination of different activities and materials. Costellor and Preller (2010) described property development as the continual combination of factors of production that is, land, labour, capital and enterprise. The scholars described property development as an integrated process revolving around numerous components.

Venter (2006) classified property development process as: idea/inception, concept refinement, preliminary feasibility, gain control of site, feasibility analysis, contract negotiation, design and documentation, financing, construction, marketing and project finalization. Different scholars had classified property development process based on their perception. Also Agunbiade (2012) classified property development process as follows; conception and design, land preparation, building construction and marketing.

Properties are developed by an investor for a motive which might not necessarily be financial. However, an investor will want to maximize satisfaction in property development even as owner occupier. Profit maximization might be in form of low cost of construction, or low maintenance cost. There are different classes of properties developed by a property developer which ranges from: residential property, commercial property, industrial property, recreational property, and agricultural property.

\subsection{Empirical Studies on Joint Venture in Construction Industry}

Paucity of literature on joint venture in property development necessitates the consideration of joint venture in construction related activities. Property development is a construction related activity with similar characteristics with other construction activities. Adnan, Chong and Morledge (2011) examined the success criteria of international joint venture in Malaysian construction industry. Data were gathered through interview of the general managers of the construction companies in the study area. Findings from the study revealed the following as critical success factors in international joint venture partner selection: reputation, inter-partner trust, experience, personal knowledge of the partner organizations, commitment and human resource management.

Kwok, Then and Skitmore (2000) examined the risk management in Singapore construction joint ventures. The study identified the preference factors for going into joint venture by construction companies in the study area. The following are the preference factors: ability to acquire new technology, strategic purposes, ability to gain reputation, not familiar but high profit margin and familiar but low profit margin. The following are the risk factors of construction joint venture; disagreement in accounting profit and loss, potential financial distress in joint venture partner, partners lack of management competence and resourcefulness, over interference by parent companies of either parties, disagreement in allocation of work, technology transfer disputes, distrust among employees from the partner's company and disagreement in allocation of staff positions in joint ventures project.

Muthonjia (2013) investigated the use of joint venture as an alternative model of construction project financing in Kenya. The following are the objectives of the study; to establish the common sources of project financing and development, to establish the hindrances to obtaining credit in construction project, to establish the use of joint venture in project financing in the study area and to determine the developers, financiers, contractors and consultant's perspective of joint ventures as a model of construction financing and investment. The 
respondents of the study included employees of Financial Institutions (Banks), Built Environment Consultants, Contractors and Developers. The sample of the study was obtained through stratified random sampling and data was gathered through questionnaires and interview. Findings from the study revealed that loan is the main source of project financing in the study area. Also, high interest rate is the major hindrance to project finance. The study revealed that industry players are pessimistic about the adoption of joint venture as a model of project financing in the study area. The study recommended that awareness should be created on the benefit of joint venture as a model for construction project financing.

Ma and Voo (2014) conducted a comparative study of construction joint venture in Australia and Malaysia. The scholars pointed out that the government of Australia and Malaysia are encouraging and supporting local contractors to implement construction joint venture based on their expertise and experiences in construction. The two pacific region countries have different experience when it comes to construction joint venture. Four in-depth case studies of construction joint venture projects were carried out by means of interviews with the contractors to compare the perceived project performance and cost risk allocation. Findings from the study suggest that the most common barriers to construction joint venture success in both Australia and Malaysian construction industries include differences in organizational policies, inconsistent management styles, a lack of mutual understanding between joint venture team members and a lack of mutually-agreed upon-conflict resolution mechanisms between joint venture contracting parties.

Romeli, Halil, Ismail and Shukor (2016) investigated the economic challenges in joint ventures infrastructure projects. The study categorized economic challenges as joint ventures into internal and external challenges. The study adopted quantitative method of research. Findings from the study revealed that the critical internal economic challenge is vague financial documentation and the critical economic challenge is legal conditions. The paper encouraged the joint venture company to implement the post counteractive act plan as an innovative business tactic to continue the joint venture's survival to augment the quality of life among contractors that execute joint venture.

\section{METHODOLOGY}

The study populations for this study are the members of the Real Estate Developers Association of Nigeria (REDAN) in Lagos. There are 1400 members of this association in Lagos according to the online directory of the association.

Sample size for Lagos will be determined quantitatively using Frankfort-Nachmias (1996) model for sample size determination as follows:-

$\mathrm{n}=\frac{\mathrm{Z}^{2} \mathrm{pqN}}{\mathrm{e}^{2}(\mathrm{~N}-1)+\mathrm{Z}^{2} \mathrm{pq}}$

Where $\mathrm{N}=$ population size

$\mathrm{p}=$ sample population estimated to have characteristics being measured (In this study, 95\% confidence level of target population)

$\mathrm{q}=1-\mathrm{p}$

$\mathrm{e}=$ Acceptable error

$\mathrm{Z}=1.96$ (The standard normal deviation at $95 \%$ confidence level)

$\mathrm{N}=1400$

$\mathrm{p}=70 \%$ or 0.7 that each sample have characteristics being measured

$\mathrm{q}=1-0.7(0.3)$

$\mathrm{e}=0.05$

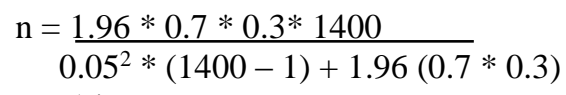

$\mathrm{n}=147$

Substitute $\mathrm{n}$ in $\mathrm{K}=\frac{\mathrm{N}}{\mathrm{n}}$

$$
\mathrm{K}=\underline{1400}
$$


147

$\mathrm{K}=9.5$ approximately 10

Systematic random sampling technique was employed in selecting the sample for the study. Every 10th member of the REDAN was considered which give a sample size of 140. Data were gathered through structured questionnaires administered to the REDAN members. Data gathered were presented and analyzed using tables, chart and Likert scale.

\section{RESULTS AND DISCUSSION}

Table 1: Questionnaires return rate

\begin{tabular}{|l|l|l|c|}
\hline & Administered & Return & Return rate \% \\
\hline Yes & 140 & 120 & 85.7 \\
\hline
\end{tabular}

Source: Field Survey, 2018

Table 1 above revealed that out of the 140 questionnaires administered to the respondents, 120 questionnaires were returned are good for analysis. The return rate of the administered questionnaires is $85.7 \%$.

Table 2: Classes of properties financed through Joint Venture

\begin{tabular}{|l|l|l|l|l|l|l|l|l|}
\hline $\begin{array}{c}\text { S } \\
/ \\
\mathbf{N}\end{array}$ & Options & $\begin{array}{c}\text { Most } \\
\text { Prevalent }\end{array}$ & Prevalent & Indifferent & $\begin{array}{c}\text { Less } \\
\text { Prevalent }\end{array}$ & $\begin{array}{c}\text { Rarely } \\
\text { Prevalent }\end{array}$ & $\begin{array}{c}\text { Relative } \\
\text { Importance } \\
\text { Index }\end{array}$ & Rank \\
\hline 1 & Residential & 70 & 30 & 12 & 3 & 5 & 4.31 & $1^{\text {st }}$ \\
\hline 2 & Commercial & 59 & 36 & 8 & 13 & 4 & 4.11 & $2^{\text {nd }}$ \\
\hline 3 & Industrial & 36 & 28 & 25 & 21 & 10 & 3.49 & $3^{\text {rd }}$ \\
\hline 4 & Recreational & 30 & 23 & 27 & 22 & 18 & 3.24 & $4^{\text {th }}$ \\
\hline 5 & Agricultural & 28 & 21 & 30 & 26 & 15 & 3.18 & $5^{\text {th }}$ \\
\hline
\end{tabular}

Source: Field Survey, 2018

Table 2 above depicts classes of properties financed by the property developers through joint venture in the study area. Residential ranked first as the most prevalent property developed by the property developers through joint venture. It has a RII of 4.31. This is followed by commercial property with a RII of 4.11. Industrial properties ranked third with a RII of 3.49. Recreational properties ranked fourth with a RII of 3.24 and Agricultural properties ranked fifth with a RII of 3.18.It can be deduced from table 2 above that residential properties is what the respondents developed most using joint venture in the study area. Also, the least developed class of property with joint venture is agricultural property.

Table 3: Nature of Parties forming Joint Venture for property development in the study area

\begin{tabular}{|l|l|l|l|l|l|l|l|}
\hline Nature & $\begin{array}{l}\text { Most } \\
\text { Prevalent }\end{array}$ & Prevalent & Indifferent & $\begin{array}{l}\text { Less } \\
\text { Prevalent }\end{array}$ & $\begin{array}{l}\text { Rarely } \\
\text { Prevalent }\end{array}$ & RII & Rank \\
\hline $\begin{array}{l}\text { Private Developer \& } \\
\text { Financial Institution }\end{array}$ & 65 & 35 & 10 & 5 & 5 & 4.25 & $1^{\text {st }}$ \\
\hline $\begin{array}{l}\text { Private Developer \& Land } \\
\text { Owners }\end{array}$ & 50 & 40 & 13 & 13 & 4 & 3.99 & 2 nd \\
\hline $\begin{array}{l}\text { Private Developer \& } \\
\text { Private Developers }\end{array}$ & 45 & 38 & 18 & 15 & 4 & 3.88 & $3^{\text {rd }}$ \\
\hline $\begin{array}{l}\text { Private Developer \& } \\
\text { Individuals }\end{array}$ & 43 & 38 & 18 & 16 & 5 & 3.82 & $4^{\text {th }}$ \\
\hline $\begin{array}{l}\text { Private Developers \& } \\
\text { Government }\end{array}$ & 23 & 30 & 14 & 18 & 3.22 & $5^{\text {th }}$ \\
\hline
\end{tabular}

Source: Field Survey, 2018 
Table 3 above depicts nature of parties coming together to form joint ventures for property development. Joint venture between private property developers and financial institutions is the most common in the study area. It ranked first with a RII of 4.25. Joint venture between private property developers and land owners is the second with a RII of 3.99. This is followed by joint venture between two private property developers with a RII of 3.88 . Joint venture between private property developers and individuals ranked fourth with a RII of 3.82 and finally, joint venture between private property developer and the government ranked fifth with a RII of 3.22 . It can be inferred from the table that financial institutions subscribe to joint venture as a model for property development. Also, it can be deuced that landowners without capacity to develop their lands adopt joint venture as a model for development. Government is the least among the parties in table 3 above that adopt joint venture as a model of property development.

Table 4: Importance of terms of Joint Venture Agreement in Property Development

\begin{tabular}{|c|c|c|c|c|c|c|c|}
\hline & $\begin{array}{l}\text { Most } \\
\text { Important }\end{array}$ & Important & Indifferent & $\begin{array}{l}\text { Less } \\
\text { Important }\end{array}$ & $\begin{array}{l}\text { Rarely } \\
\text { Important }\end{array}$ & Mean & Rank \\
\hline Financing & 60 & 26 & 10 & 14 & 10 & 3.93 & $1^{\text {st }}$ \\
\hline Profit Sharing & 56 & 30 & 6 & 10 & 18 & 3.80 & $2^{\text {nd }}$ \\
\hline License & 52 & 18 & 13 & 25 & 12 & 3.61 & $3^{\text {rd }}$ \\
\hline $\begin{array}{l}\text { Divesting from } \\
\text { investment }\end{array}$ & 47 & 15 & 11 & 28 & 19 & 3.36 & $4^{\text {th }}$ \\
\hline $\begin{array}{l}\text { Managerial Post } \\
\text { allocation }\end{array}$ & 46 & 11 & 10 & 23 & 30 & 3.17 & $5^{\text {th }}$ \\
\hline $\begin{array}{l}\text { Additional } \\
\text { Capital }\end{array}$ & 42 & 11 & 12 & 17 & 39 & 3.03 & $6^{\text {th }}$ \\
\hline Risk & 40 & 10 & 15 & 14 & 41 & 2.95 & $7^{\text {th }}$ \\
\hline $\begin{array}{l}\text { Investment } \\
\text { Period }\end{array}$ & 36 & 9 & 17 & 25 & 33 & 2.92 & $8^{\text {th }}$ \\
\hline $\begin{array}{l}\text { Acquisition of } \\
\text { equipment }\end{array}$ & 33 & 9 & 15 & 28 & 35 & 2.81 & $9^{\text {th }}$ \\
\hline
\end{tabular}

Source: Field Survey, 2018

From table 4 above, the most important term in a joint venture agreement is financing. It has a RII of 3.93 and it ranked first. This is followed by profit sharing that ranked second with a RII of 3.80. License or approval for operation ranked third with a RII of 3.61. Also, divesting from investment ranked fourth with a RII of 3.36, allocation of managerial posts ranked fifth with a RII of 3.17. Need for additional capital ranked sixth with a RII of 3.03, risk ranked seventh with a RII of 2.95. Duration of investment ranked eight with a RII of 2.92 and acquisition of equipments ranked ninth with a RII of 2.81 .

Table 5: Problems of Joint Venture in Property development

\begin{tabular}{|l|l|l|l|l|l|l|l|}
\hline Problems & $\begin{array}{l}\text { Most } \\
\text { Prevalent }\end{array}$ & Prevalent & Indifferent & $\begin{array}{l}\text { Less } \\
\text { Prevalent }\end{array}$ & $\begin{array}{l}\text { Rarely } \\
\text { Prevalent }\end{array}$ & RII & Rank \\
\hline Problem of financing & 52 & 33 & 12 & 13 & 10 & 3.87 & $1^{\text {st }}$ \\
\hline $\begin{array}{l}\text { Problem of profit } \\
\text { sharing }\end{array}$ & 50 & 29 & 10 & 10 & 21 & 3.64 & $2^{\text {nd }}$ \\
\hline Distrust & 48 & 25 & 7 & 16 & 24 & 3.48 & $3^{\text {rd }}$ \\
\hline Technology transfer & 44 & 23 & 7 & 18 & 28 & 3.31 & $4^{\text {th }}$ \\
\hline Staffing & 42 & 22 & 8 & 18 & 30 & 3.23 & $5^{\text {th }}$ \\
\hline $\begin{array}{l}\text { Government } \\
\text { Regulation }\end{array}$ & 40 & 22 & 8 & 17 & 33 & 3.16 & $6^{\text {th }}$ \\
\hline Corruption & 38 & 20 & 7 & 20 & 35 & 3.05 & $7^{\text {th }}$ \\
\hline Risk burden & 34 & 19 & 7 & 20 & 40 & 2.89 & $8^{\text {th }}$ \\
\hline Breach of Agreement & 30 & 17 & 6 & 22 & 45 & 2.71 & $9^{\text {th }}$ \\
\hline
\end{tabular}

Source: Field survey 2018 
From table 5above, the most prevalent problem of joint venture in property development in the study area is financing. It has a RII of 3.87 and it ranked first. This followed by problem of profit sharing that ranked second with a RII of 3.64. Distrust among joint venture partners ranked third with a RII of 3.48, problem of technology transfer ranked fourth with a RII of 3.31. This is followed by problem of staffing which ranked fifth with a RII of 3.23. Problem arising from government regulation ranked sixth with a RII of 3.16. This is followed by corruption that ranked seventh with a RII of 3.05. Also, problem of risk burden ranked eight with a RII of 2.89 and breach of joint venture agreement ranked ninth with a RII of 2.71 .

\section{CONCLUSION}

Joint venture is a business model that gives edge to parties adopting it for business financing. It is applicable in different fields of which property development is not exempted. It was deduced from the study that property developers do adopt joint venture as a financing tool for different classes of properties. The most prevalent class of property developed through joint venture in the study area is residential property. Also, it was discovered that the most common joint venture arrangement in the study area is between private property developers and the financial institutions. There are important provisions of a joint venture agreement that need to be well discussed by parties going into joint venture before signing the agreement. The associated problems of joint venture could be prevented if there is adequate discussion between parties before going into joint venture. In conclusion, Joint ventures adoption among parties involved in property development should be improved on.

\section{RECOMMENDATIONS}

Joint ventures should be adopted for the development of all classes of property. It was discovered that joint venture was predominantly used in developing residential properties and commercial properties in the study area. Private property developers should adopt it as a model for property development. The government should adopt joint venture as a model for property development. It was discovered that joint venture between private property developers and the government ranked least in the study area. Terms in joint venture agreement should be well discussed by parties involved in joint venture before drafting the agreement. None of the terms of joint venture agreement should be seen as less important. Parties involved in joint venture should sort out problem of financing before going into a joint venture. Also, other joint venture associated problems should be prevented at the joint venture agreement drafting stage. Provision for dispute reconciliation should be included in a joint venture agreement. Litigation should be avoided as a means of dispute resolution by parties going into a joint venture. Alternative dispute resolution mechanisms should be embraced. Finally, further researches should be conducted on the nature of relationship between parties going into joint ventures and how it affects property development.

\section{REFERENCES}

Adnan, H, Chong, H-Y and Morledge, R (2011) Success Criteria for International Joint Ventures: The experience of Malaysian Contractors in the Middle East. African Journal of Business Management, 5(13), 52545260, DOI: 10.5897/AJBM11.02

Agunbiade, M.E. (2012) Land Administration for Housing Production. Unpublished PhD thesis submitted to the University of Melbourne, Australia.

Altona, I (2008) Residential Property Development: A Framework for Successful Developments. An Unpublished Bachelors of Industrial Engineering thesis submitted to the Faculty of Engineering, Built Environment and Information Technology, University of Pretoria.

Ahmed, R S H and Ahmed, S S H (2013) The Future of Joint Ventures: Literature Review. International Journal of Business and Management Studies, 5(2), $230-240$.

Bilas, V, Cenan, D and Podrug, N (2007) The problems associated with managing international joint venture in Croatia. Being a Conference proceeding for the International Conference on Economics and Management of Networks (EMNet), Rotterdam. 
Channon, D.F and Sammut-Bonnici, T (2014) Joint Ventures. Wiley Encyclopedia, John Wiley \& Sons, Ltd

Costello, G and Preller, F (2010) Property Development Principles and Process-an Industry Analysis. 16th PacificRim Real Estate Society Conference Wellington, New Zealand, 24th to 27th January, 2010.

Grades, Z E A (2008) Market Entry and Expansion through International Joint Venture: A Multi-casual Analysis of International Joint Venture Performance. Being an Unpublished PhD thesis submitted to Universität Bergakademie Freiberg genehmigte.

Kogut, B (1988) Joint Ventures: Theoretical and Empirical Perspectives. Strategic Management Journal, Vol. 9 $319-332$.

Kwok, H.C.A. and Then, D and Skitmore, M (2000) Risk Management in Singapore Construction Joint Ventures. Journal of Construction Research 1(2):pp. 139-149.

Ma T and Voo, T (2014) A Comparative Study of Construction Joint Ventures in Australia and Malaysia. Being a conference proceeding of EPPM Conference at Port Elizabeth, South Africa.

Miller, R, W (2004) Joint Ventures in Construction. Textbook Published by National Association of Surety Bond Producer, Third Edition.

Muthonjia, K.A (2013) An Investigation into the Use of Joint Ventures an Alternative Model of Construction Project Financing. Being an Unpublished Bachelor in Quantity Survey dissertation, submitted to the University of Nairobi, Kenya.

Romeli, N, Halil, F.M, Ismail, F and Abd Shukor, A. S (2016) Economic Challenges in Joint Venture Infrastrutural Projects: Towards Contractor's Quality of Life. AMER International Conference on Quality of Life, Medan, Indonesia, Procedia - Social and Behavioral Sciences 234, 19 - 27.

Salmon, B. (2015) Real Estate Development Joint Ventures, Briefing a Burgess-Salmon Publications. www.burgess-salmon.com.

Venter I (2006) Inter Continental Heliopolis Hotel Strategic Marketing Plan (2001 to 2005): MBA Strategic Marketing Module Assignment, School of Hotel and Restaurant Management, Oxford Brooks University. 